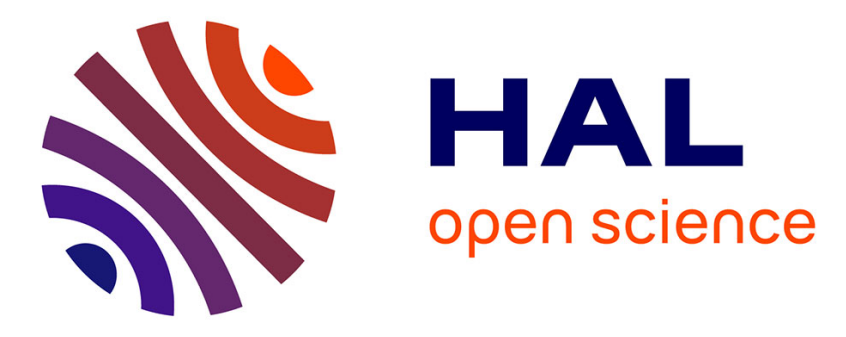

\title{
Perception of affects from non-facial expressions of the robot Nabaztag
}

\author{
Ya-Huei Wu, Victoria Cristancho-Lacroix, E. Gabillet, Jade Le Maître, \\ Mohamed Chetouani, Céline Jost, Brigitte Le Pévédic, Dominique Duhaut, \\ Anne-Sophie Rigaud
}

\section{To cite this version:}

Ya-Huei Wu, Victoria Cristancho-Lacroix, E. Gabillet, Jade Le Maître, Mohamed Chetouani, et al.. Perception of affects from non-facial expressions of the robot Nabaztag. ISG, International Society for Gerontechnology/ISARC, International Symposium of Automation and Robotics in Construction, Jun 2012, Eindhoven, Netherlands. hal-00745752

\section{HAL Id: hal-00745752 \\ https://hal.science/hal-00745752}

Submitted on 26 Oct 2012

HAL is a multi-disciplinary open access archive for the deposit and dissemination of scientific research documents, whether they are published or not. The documents may come from teaching and research institutions in France or abroad, or from public or private research centers.
L'archive ouverte pluridisciplinaire HAL, est destinée au dépôt et à la diffusion de documents scientifiques de niveau recherche, publiés ou non, émanant des établissements d'enseignement et de recherche français ou étrangers, des laboratoires publics ou privés. 
Y-h Wu, V Cristancho-Lacroix, E Gabillet, J Le Maître, M Chetouani, C Jost, B Le PeVedic, D DUhAUT, A-S RIGAUD. Perception of affects from non-facial expressions of the robot Nabaztag. Gerontechnology 2012; 11(2):xxx; doi:10.4017/gt.2012.11.02.xxx.xx Purpose Social robots using language and affective expressions can encourage and improve human-robot interaction. Body movements, postures, orientations, colors, and sounds can be used as either the primary method of expression or to provide affective expression redundancy ${ }^{1}$. This study aimed at investigating how the elderly and the young perceive affects from expressions of Nabaztag, a non anthropomorphic robot with only non facial expressions. Method Twenty college students (20-34 years old; 11 men, 9 women) and 23 elderly (62-85 years old; 4 men, 19 women) were recruited. Nabaztag was programmed to have 27 expressions (3 colours: green/blue/red ${ }^{\star} 3$ ear positions: horizontal/vertical/asymmetric ${ }^{\star} 3$ levels of speed of light blinking: rapid/slow/continuous). Subjects were asked to categorize each expression into one of the 8 affects (surprise, enthusiasm, joy, calmness, inactiveness, boredom, sadness, frustration). Results \& Discussion Colours had influence in perception of some affects for both groups. When the elderly and the young perceived Nabaztag as calm, the blue colour was most frequently attributed to this affect $\left(\mathrm{X}^{2}(2\right.$, $\mathrm{N}=100)=8.54, \mathrm{p}=0.014 ; \mathrm{X}^{2}(2, \mathrm{~N}=63)=24.67, \mathrm{p}<0.01$. $)$. Only for the young, enthusiasm and joy weremostly associated to green colour $\left(X^{2}(2, N=67)=25.91, p<0.01 ; X^{2}(2, N=84)=20.86, p<0.01\right)$ while frustration was highly related to the red colour $\left(X^{2}(2, N=63)=60.10, p<0.01\right)$. As for light blinking speeds, this variable didn't have any influence on the perception of affects for the elderly. For the young, perception of enthusiasm was mostly related to rapid light blinking $\left(\mathrm{X}^{2}(2, N=67)=8.27, p=0.016\right)$, while perception of calmness was associated to slow light blinking, $X^{2}(2, N=63)=6.10, p=0.047$. Finally, ear positions also had effect on perception of some affects. For the elderly as for the young, perception of positive affects, such as enthusiasm $\left(X^{2}(2, N=78)=53.154, p<0.01 ; X^{2}(2, N=67)=18.746, p<0.01\right)$ and joy $\left(X^{2}(2, N=104)\right.$ $\left.=23.096, p<0.01 ; X^{2}(2, N=84)=12.214, p=0.002\right)$ was the most often attributed to vertical position of both ears. Uniquement for the elderly, perception of boredom and surprise was mostly related to asymmetric position of both ears $\left.\left(X^{2}(2, N=55)=12.036, p=0.002\right) ; X^{2}(2, N=74)=11.541, p=0.003\right)$, while perception of calmness was mostly associated to the horizontal position of both ears $\left(X^{2}(2, N=100)=6.14, p=0.046\right)$.

\section{References}

1. Cindy L. Bethel, Robin R. Murphy (2008). Survey of Non-facial/Non-verbal Affective Expressions for Appearance-Constrained Robots. IEEE TRANSACTIONS ON SYSTEMS, MAN, AND CYBERNETICSPART C: APPLICATIONS AND REVIEWS, 38, 83-92.

Keywords: expressive robotic behaviour, human-robot interaction, affective computing Address: Broca Hospital, 54-56, rue Pascal, 75013, Paris

E-mail: yahuei.wu@brc.aphp.fr 